\title{
Punica granatum L. (pomegranates) from early Roman contexts in Vindonissa (Switzerland)
}

\author{
Stefanie Jacomet ${ }^{\mathfrak{1}}$, Dušanka Kučan ${ }^{2}$, Axel Ritter ${ }^{3}$, Georg Suter ${ }^{4}$ and Andrea Hagendorn ${ }^{5}$ \\ 'Universität Basel, Seminar für Ur- und Frühgeschichte, Abteilung Archäobiologie/Archäobotanik, c/o Botanisches Institut, \\ Schönbeinstrasse 6, CH-4056 Basel, Switzerland. e-mail: stefanie.jacomet@unibas.ch \\ ${ }^{2}$ Niedersächsisches Institut für historische Küstenforschung, Postfach 2062, D-26360 Wilhelmshaven, Germany. e-mail: \\ Dusanka.Kucan@nihk.terramare.de \\ ${ }^{3}$ EMPA Eidgenössische Materialprüfungs- und Forschungsanstalt, Lerchenfeldstrasse 5, CH-9014 St. Gallen, Switzerland. \\ e-mail: axel.ritter@empa.ch \\ ${ }^{4}$ Sicherheitsinstitut (Schweizerisches Institut zur Förderung der Sicherheit), c/o Novartis Klybeckstrasse, Postfach, CH-4002 \\ Basel, Switzerland. e-mail: GSuter@swissi.ch \\ ${ }^{5}$ Kantonsarchäologie Aargau, Industriestrasse 3, CH-5200 Brugg, Switzerland. e-mail: Andrea.Hagendorn@ag.ch
}

Received November 22, 2001 / Accepted February 19, 2002

\begin{abstract}
At the later legionary camp of Vindonissa, early Roman (Augustan-Claudian) structures were excavated during a rescue excavation between 1996 and 1998. In phase 2 ( 10 B.C. until 0), seven in situ carbonised wooden barrels, dug into the ground, were found. They belonged to a rather large building which was most probably used as storage facility. Two of the barrels contained, in the bottom layers, several hundred seeds and pericarp fragments of Punica granatum L. (pomegranates). A large number of other "exotic" plant taxa such as olive, walnut, pine, pistacio, peach, cherry (and probably date) were also found in rather large quantities. Above all, the finds of pomegranates are unique: they are the first finds of this Mediterranean fruit in regions north of the Alps. The origin, use, and other archaeological finds of the pomegranate in the Roman period are discussed. A comparison with other early Roman spectra shows that such large quantities of "exotic" useful plants are mainly present at larger military sites like the legionary camps of Novaesium or Oberaden. It must also be suggested that the pre-camp phases in Vindonissa already had a military character, although this is not at all clear from the other archaeological finds. The precise role of the site is still a matter of debate.
\end{abstract}

Key words: Roman period - Pomegranates - Storage barrels - Carbonisation experiments - Switzerland

\section{Introduction: the site and dates of the structures, aims} of the research

Roman influence in Switzerland began early. The southwesternmost part, the Region of Geneva, became part of the province Gallia Narbonensis in 121 B.C. In 44 B.C., the first coloniae were founded. With the conclusion of the so called "Alpenfeldzug" at 15 B.C., the whole country was incorporated into the Roman empire (historical data after Drack and Fellmann 1988; Furger et al. 2001).

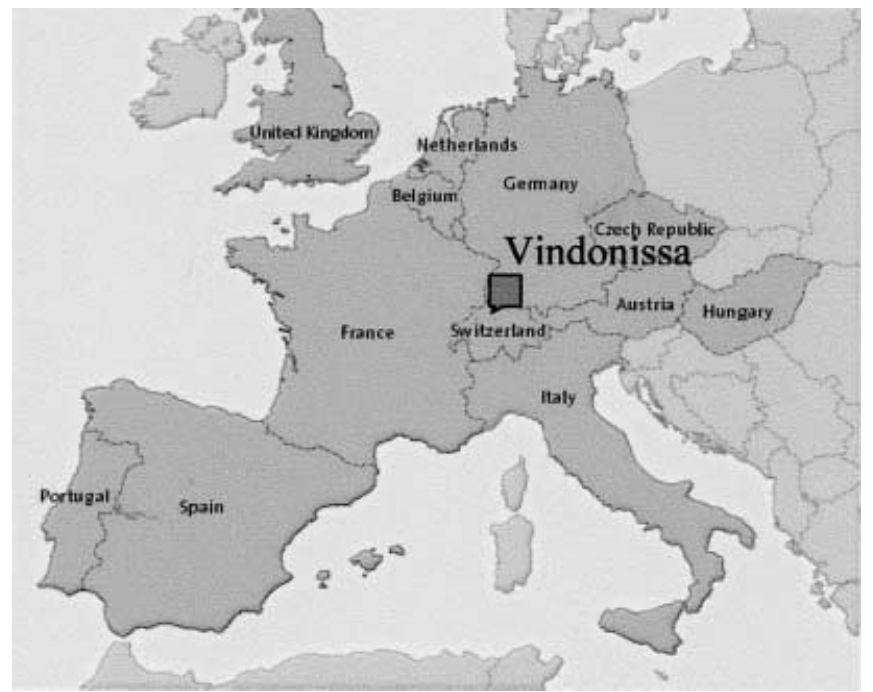

Fig. 1. Map of Europe showing the location of Switzerland and Vindonissa

Vindonissa (today called Windisch, near Brugg, canton of Aargau) is situated in the northern part of the Swiss plateau (Fig. 1); it is located on a terrace between the rivers Aare and Reuss and so has a good strategic position. At this location, in early Tiberian times, at about A.D. 15 20, the LEGIO XIII founded a legionary camp with wooden buildings. After A.D. 45, the XIII was replaced by the LEGIO XXI, which was stationed there until A.D. 69/ 70. Afterwards, the LEGIO XI replaced the XXI. These two legions substituted the wooden buildings with stone buildings. Vindonissa is the only large military camp in the area of Switzerland. However, the location was settled much earlier, as was confirmed by a new excavation at "Breite" between 1996 and 1998 under the direction of Andrea Hagendorn of the Kantonsarchäologie Aargau (Fig. 2). This excavation took place on the spot of the later principia of the 21 st and 11 th legion, erected after A.D. 45. It provided a sequence of seven timber building phases (HP), starting in early Augustan times and lasting until about A.D. 45 (see Hagendorn et al., in press): 
HP 1: before 10 B.C. (no samples)

HP 2: 10 B.C. - 0 (18 samples)

HP 3: A.D. 0-10 (9 samples)

HP 4: A.D. 10-15 (6 samples)

HP 5: A.D. 15-22/25 (Legio XIII?) (5 samples)

HP 6: A.D. 22/25-37/40 (Legio XIII) (3 samples)

HP 7: A.D. 37/40-45 (Legio XXI) (18 samples)

Dating of the phases was mainly on the basis of ceramics (Meyer-Freuler, in Hagendorn et al., in press), but also by coins (Doppler, in Hagendorn et al., in press).

In Vindonissa, it is probable that important roads already met in Augustan times: one from the west (from the colonia of Augusta Raurica) to the east (towards Pannonia), and probably one from the south of the Alps to the north. These connections were of great importance because they were the main supporting roads for the Augustan legionary camp of Dangstetten and an early fort at Zurzach (Tenedo), situated at the frontier formed by the Rhine, at a distance of about 20 to $25 \mathrm{~km}$ from Vindonissa. Therefore, it should be assumed that Vindonissa already had a certain importance in Augustan times.

Until now, almost no botanical investigations have been undertaken at Vindonissa. There were only some old investigations of the so-called "Schutthügel" (rubbish heap) by Neuweiler $(1908,1927)$ and Baas (1987); there, the material investigated cannot be dated precisely. The studies presented here are therefore the first modern systematic archaeobotanical investigations of this important site. The main aim of the interdisciplinary evaluation project of the site "Breite" was to define the nature of the site, whether military or civil, before the arrival of the first legion, and to define what was its role in the wider regional context. The archaeobotanical material should give clues to the interpretation of single structures, but also to the nature of the site through the analysis of the spectra of useful plants.

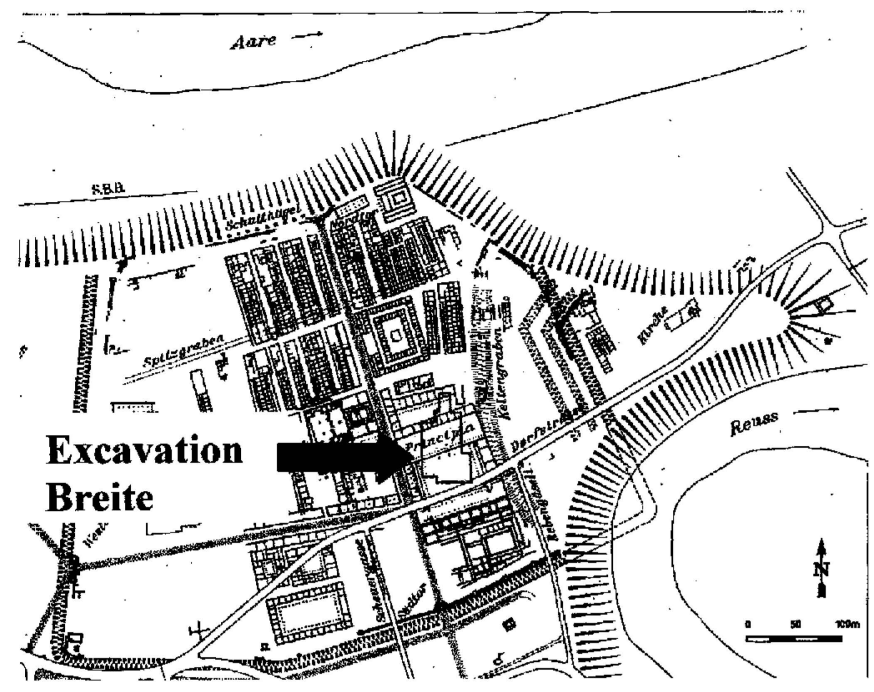

Fig. 2. Map of the legionary camp of Vindonissa around A.D. 100 ; the Breite excavation is situated in the region of the principia (Drack and Fellmann 1988)

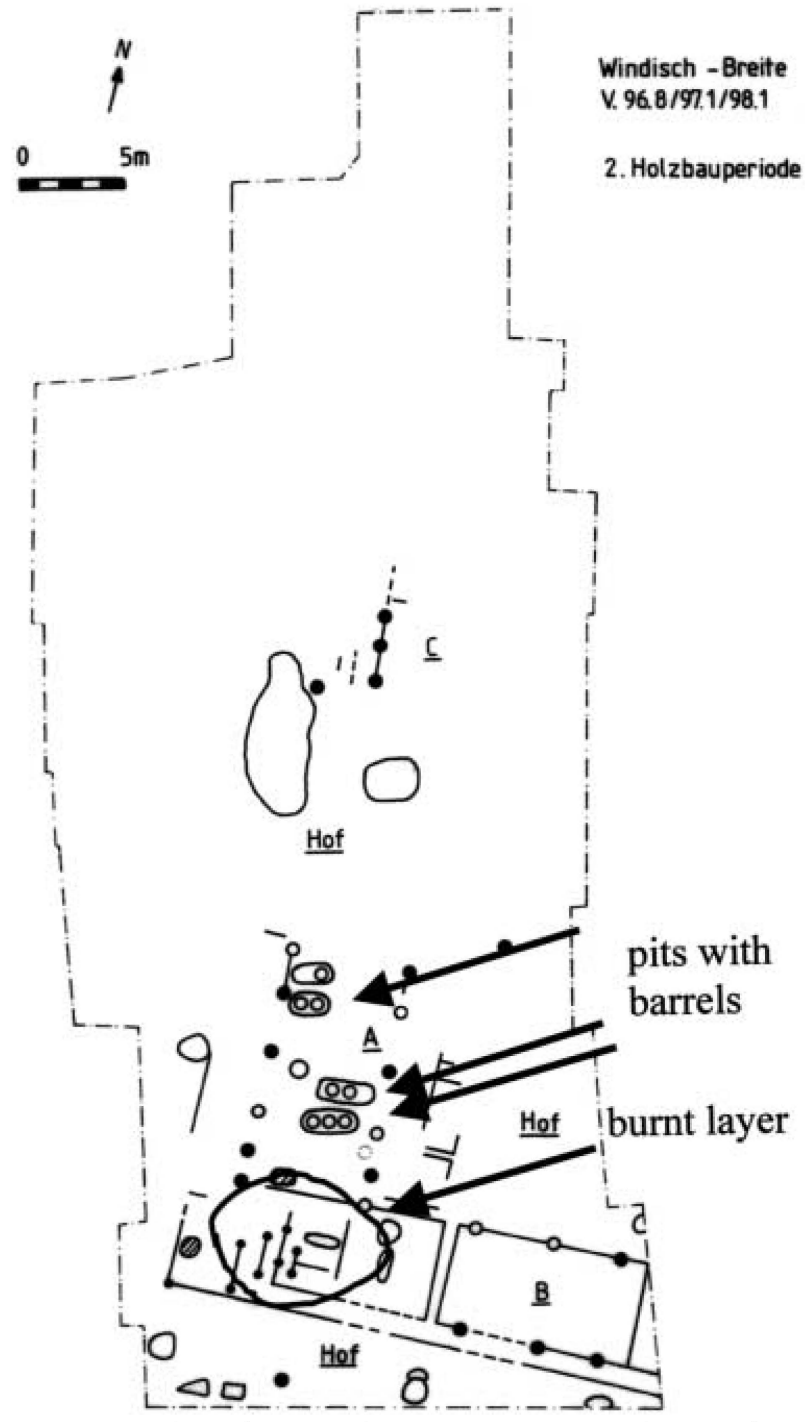

Fig. 3. Plan of the timber building phase (HP) 2, from early Augustan times (10 B.C. - 0). Map by Kantonsarchäologie Aargau

\section{Materials and Methods \\ Preservation of organic materials, structures and sam- pling}

The site is situated on dry, minerogenic soils. Therefore, only carbonised and mineralised plant material was preserved. A systematic sampling was carried out during the excavations at the site. As many structures as possible were sampled. In total, we analysed 59 samples with a total volume of 533 litres from phases HP 2 to 7 (for number of samples per phase, see the list in the introduction).

The plant remains mainly derive from pits of different shape. In the following we will concentrate on the structures of phase HP 2 (10 B.C. - 0) (Fig. 3). In this phase, the remains of a large building (A, about $14 \times 20 \mathrm{~m}$ in diameter, see Fig. 3) were found; it was probably used for storage. This is indicated by large amounts of sherds of dolia and amphorae, and also by five pits in which seven wooden half-barrels, dug about $50 \mathrm{~cm}$ into the ground, were preserved in situ (Fig. 4). These barrels were filled with burnt material to the bottom (Fig. 4). The excavator (A. Hagendorn) supposes that the fill represents material burnt in situ, at least partly. 


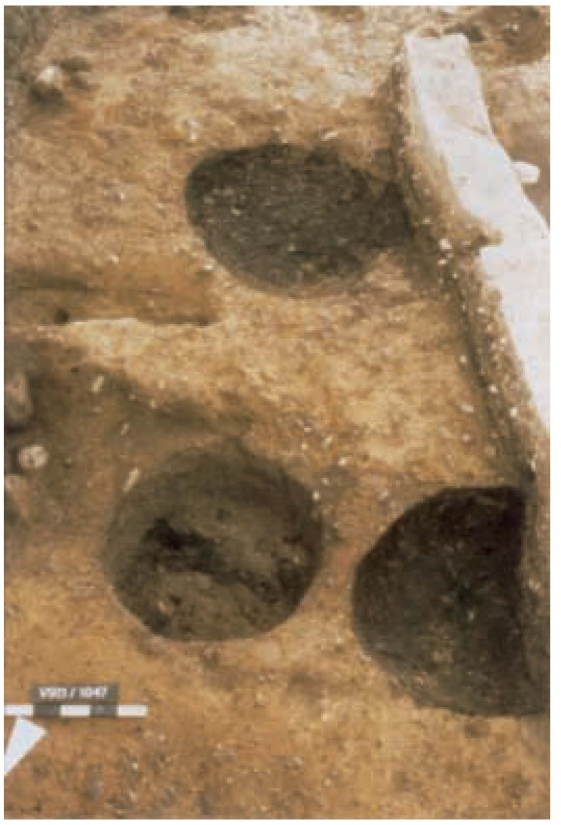

Fig. 4. Some of the carbonised wooden barrels of HP 2. Photograph by Kantonsarchäologie Aargau

In the area south of the barrels, a burnt layer was preserved. Between the fill of the southern group of barrels (field 34; Fig. 3 ) and the burnt layer many "Passscherben" (joining sherds from the same vessel) were found: this indicates that after the destruction of the whole building there were intensive levelling activities.

Wooden barrels served in Roman times as wine transport vessels (see, for example, Desbat 1997). Empty barrels were reused as linings for wells, latrines (known for instance from waterlogged sites such as the legionary camp of Oberaden, Kučan 1992), or probably also as underground stores; on dry sites they are preserved only when they are carbonised in situ as at Vindonissa. Other examples are known for instance from southern France (Lattes, Fréjus; see Desbat 1997), and for example also from late Iron Age Manching (Maier 1985). Finds of this kind are therefore very rare.

The sampling of the seven barrels was not uniform: only two, in the northern part of the building, could be sampled properly, following the structures. A bottom layer could then be rela-

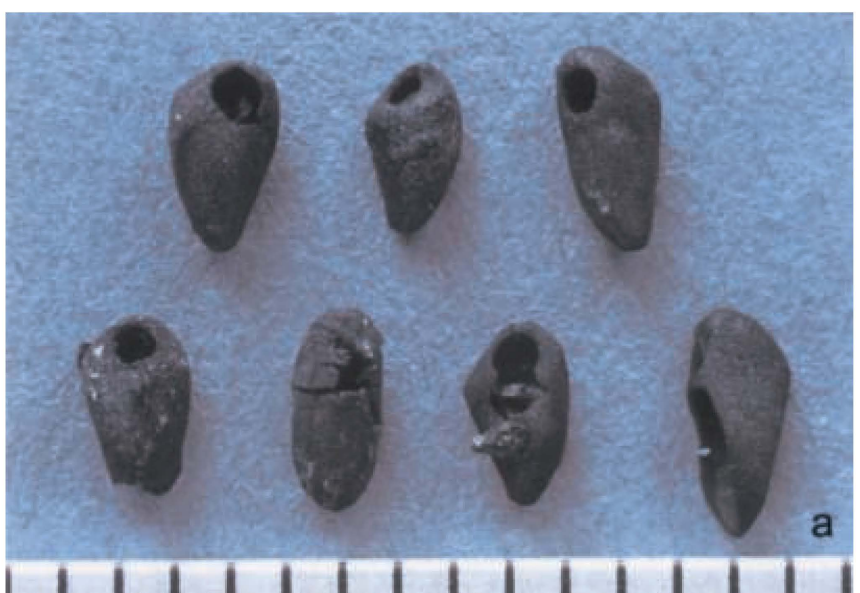

Fig. 5a. Carbonised seeds of Punica granatum L. (pomegranates) from the wooden barrels of HP 2. Photograph by U. M. Weber, Larix Consult, Basel tively clearly separated from a later fill layer. In the other barrels, it was not possible to differentiate these layers so clearly. But there too, two samples were taken if possible: one from the bottom, and one from the later fill. The thickness of the sampled layers was between 5 and $10 \mathrm{~cm}$.

\section{Preparation of the samples, analysis and identification}

Most of the samples (with an average volume of about 10 litres) were already sieved at the excavation, others in the laboratory at Basel University. The sieve meshes used were $4 \mathrm{~mm}, 1 \mathrm{~mm}$ and $0.35 \mathrm{~mm}$. Whereas the organic material from the $4 \mathrm{~mm}$ and $1 \mathrm{~mm}$ fractions was analysed in full, the $0.35 \mathrm{~mm}$ fraction was only randomly checked, because of shortage of time and money. We believe that the analysis of the $1 \mathrm{~mm}$ fraction is precise enough to reconstruct to a large extent the function of the structures; it is also possible to get a rather good overview of the spectrum of useful plants. Of course, it is not possible to reconstruct the weed flora, and useful plants with small seeds, such as fig, are underrepresented.

Identification took place with the help of the known literature (see compilation in Jacomet and Kreuz 1999) and the reference collection at Basel University. The pomegranate seeds were identified by D. Kučan, based on her work in the antique Heraion on Samos (Kučan 1995). We also tried to identify the over 7000 pieces of "amorphous" carbonised objects. For this we artificially carbonised the most common fruits introduced by the Romans to central Europe (for example Prunus species (plums), Phoenix (dates), Ficus (figs), Malus (apples), Cucumis (melon), the pericarp of Punica granatum (pomegranate) at $250^{\circ} \mathrm{C}$ in sand in a stove. However, only a minor part could be identified to genus level because the structures are only rarely specific (see Jacomet in press; Narten 1999).

\section{Carbonisation experiments and "crush test"}

The carbonisation experiments had two aims: one was to find out if it is possible that organic materials were carbonised in situ in the wooden barrels, $50 \mathrm{~cm}$ deep in the ground. The second was to test whether whole in situ carbonised fruits can break into small pieces by the levelling activities after the fire which destroyed the building. The experiments were carried out with pomegranates which were by far the most frequent fruit remains, especially in the bottom layers of two barrels (see results).

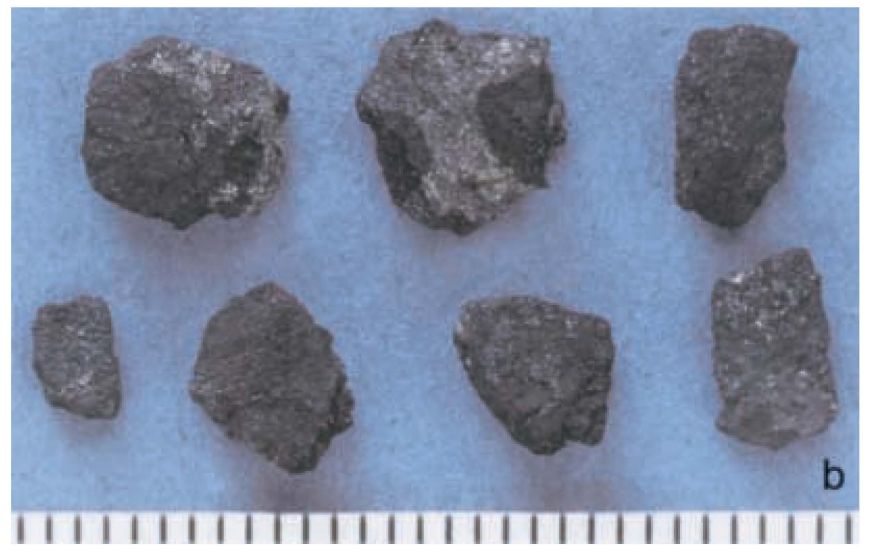

Fig. 5b. Carbonised pericarp fragments of Punica granatum L. (pomegranates) from the wooden barrels of HP 2. Photograph by U. M. Weber, Larix Consult, Basel 
Table 1. Carbonised remains of useful plants in the Augustan phases 2-4 in Vindonissa-Breite. Scientific plant names partly after Binz and Heitz (1990), cultivated plants after Zohary and Hopf (2000). In the totals also not mentioned items are included.

\begin{tabular}{|c|c|c|c|c|c|c|}
\hline species & $\begin{array}{l}\text { type of remain } \\
\text { (carbonised) }\end{array}$ & $\begin{array}{c}\text { HP } 2 \\
\text { only barrels } \\
\text { (10 samples })\end{array}$ & $\begin{array}{c}\text { HP } 2 \\
\text { all } 18 \text { samples } \\
(1551)\end{array}$ & $\begin{array}{c}\text { HP 3 } \\
9 \text { samples } \\
\text { (1011) }\end{array}$ & $\begin{array}{c}\text { HP } 4 \\
6 \text { samples } \\
(601)\end{array}$ & Total \\
\hline \multicolumn{7}{|l|}{ 1. Cereals } \\
\hline Panicum miliaceum & & 127 & 448 & 56 & 203 & 707 \\
\hline Setaria italica & & 1 & 1 & - & - & 1 \\
\hline total millets & & 131 & 491 & 57 & 207 & 755 \\
\hline Avena spec.grains & & 2 & 2 & 2 & 1 & 5 \\
\hline Hordeum vulgare/distichon & grain & 4 & 10 & 2 & 5 & 17 \\
\hline Triticum cf turgidum/durum/aestivum & grain & - & - & - & 32 & 32 \\
\hline Triticum dicoccum & glume base & - & 1 & - & - & 1 \\
\hline Triticum cf dicoccum & glume base & - & 1 & 9 & 9 & 19 \\
\hline Triticum cf dicoccum & grain & 3 & 3 & 2 & 2 & 7 \\
\hline Triticum dicoccum/spelta & glume base & - & 2 & 1 & 1 & 4 \\
\hline Triticum dicoccum/spelta & grain & - & - & - & 8 & 8 \\
\hline Triticum spelta & sprouted grain & - & - & - & 1 & 1 \\
\hline Triticum spelta & grain & 4 & 8 & 6 & 56 & 70 \\
\hline Triticum cf spelta & grain & 4 & 9 & - & 64 & 73 \\
\hline Trilicum spelia & spikelet fork & 2 & 2 & - & - & 2 \\
\hline Triticum spelta & glume base & 97 & 114 & 82 & 152 & 348 \\
\hline Triticum of spelta & glume base & 10 & 10 & - & 27 & 37 \\
\hline Triticum monococcum & spikelet fork & 1 & 1 & - & - & 1 \\
\hline Triticum monococcum & glume base & 2 & 2 & 1 & - & 3 \\
\hline Triticum ef monococcum & grain & - & - & - & - & 0 \\
\hline Triticum spec. & grain & 3 & 13 & 10 & 148 & 171 \\
\hline Cerealia & grain-fragment & 126 & 529 & 93 & 752 & 1374 \\
\hline Cerealia & embryo & 1 & 1 & - & - & 1 \\
\hline Cerealia & chaff & - & - & - & 2 & 2 \\
\hline total cereals with big grains & & 261 & 728 & 214 & 1266 & 2208 \\
\hline total of all cereals & & 392 & 1219 & 271 & 1473 & 2963 \\
\hline \multicolumn{7}{|l|}{ 2. Pulses } \\
\hline Lens culinaris & & 3 & 4 & - & 3 & 7 \\
\hline Pisum sativum & & 1 & 1 & 7 & 1 & 9 \\
\hline Vicia faba & & 2 & 6 & $i$ & 1 & 8 \\
\hline total of pulses & & 7 & 14 & 22 & 10 & 46 \\
\hline oil plants & & - & - & - & - & 0 \\
\hline Olea europaea & stone fragment & - & 1 & 1 & - & 2 \\
\hline total of oil plants & & 6 & 7 & 1 & - & 8 \\
\hline \multicolumn{7}{|l|}{ 3. Nuts and nutlike plants } \\
\hline Corylus avellana & shell fragment & 170 & 259 & 387 & 50 & 696 \\
\hline Juglans regia & shell fragment & 5 & 9 & 22 & 1 & 32 \\
\hline Pinus pinea & shell fragment & 1 & 1 & - & - & 1 \\
\hline Pistacia spec. & shell fragment & $i$ & $i$ & - & - & 1 \\
\hline total of nuts and nutlike plants & & 186 & 290 & 414 & 53 & 757 \\
\hline \multicolumn{7}{|l|}{ 4. Apples and pears } \\
\hline Maloideae & fruit fragment & 1 & 1 & - & 2 & 3 \\
\hline Malus spec. & seed fragment & 1 & 1 & 3 & - & 4 \\
\hline total of apples and pears & & 3 & 3 & 4 & 2 & 9 \\
\hline \multicolumn{7}{|l|}{ 5. Stone fruits } \\
\hline Prunus persica & stone fragment & - & - & 1 & - & 1 \\
\hline Prunus avium/cerasus & stone fragment & - & - & - & 2 & 2 \\
\hline Prunus insititialdomestica & stone fragment & - & - & - & 1 & 1 \\
\hline Prunus spinosa & stone fragment & 2 & 2 & 7 & - & 9 \\
\hline Varia & stone fragment & - & - & - & 1 & 1 \\
\hline total of stone fruits & & 2 & 2 & 8 & 4 & 38 \\
\hline \multicolumn{7}{|l|}{ 6. Other fruits } \\
\hline Punica granatum & seed & 425 & 430 & 3 & 9 & 442 \\
\hline Punica granatum & pericarp & 353 & 353 & - & - & 353 \\
\hline cf Punica granatum & pericarp & 608 & 621 & 2 & 33 & 656 \\
\hline ef Phoenix dactylifera & pericarp & 316 & 333 & 5 & 8 & 346 \\
\hline cf Ficus carica & fruit flesh & 1 & 1 & - & - & 1 \\
\hline Rubus fruticosus & fruit & 2 & 2 & 1 & - & 3 \\
\hline Sambucus nigra/racemosa & seed & - & 2 & - & - & 2 \\
\hline Varia & stalk & - & 2 & - & 1 & 3 \\
\hline cf Cucumis melo & pericarp & 26 & 27 & - & - & 27 \\
\hline \multirow{2}{*}{\multicolumn{2}{|c|}{$\begin{array}{l}\text { total of other fruits } \\
\text { 7. Various fruit flesh remains (not determinable) }\end{array}$}} & 1733 & 1773 & 12 & 52 & 1837 \\
\hline & & 255 & 332 & 48 & 138 & 518 \\
\hline \multicolumn{2}{|c|}{ 8. Various amorphous objects (probably fruit flesh) } & 4228 & 4841 & 482 & 385 & 5708 \\
\hline total of edible useful plants & & 6836 & 8505 & 1262 & 2117 & 11884 \\
\hline total of secds of wild plants & & 161 & 359 & 125 & 112 & 596 \\
\hline Indeterminata & & 14 & 196 & 2 & 1 & 199 \\
\hline Varia & & 128 & 155 & 128 & 87 & 370 \\
\hline Total of carbonised varia and indet & & 142 & 351 & 130 & 88 & 569 \\
\hline vegetative plant remains & & & & & & \\
\hline curved objects & & 250 & 250 & 2 & - & 252 \\
\hline other remains & & 11 & 16 & 1 & 33 & 50 \\
\hline total of vegetative plant remains & & 261 & 266 & 3 & 33 & 302 \\
\hline total of carbonised plant remains (with & charcoal) & 7400 & 9481 & 1520 & 2350 & 13351 \\
\hline
\end{tabular}



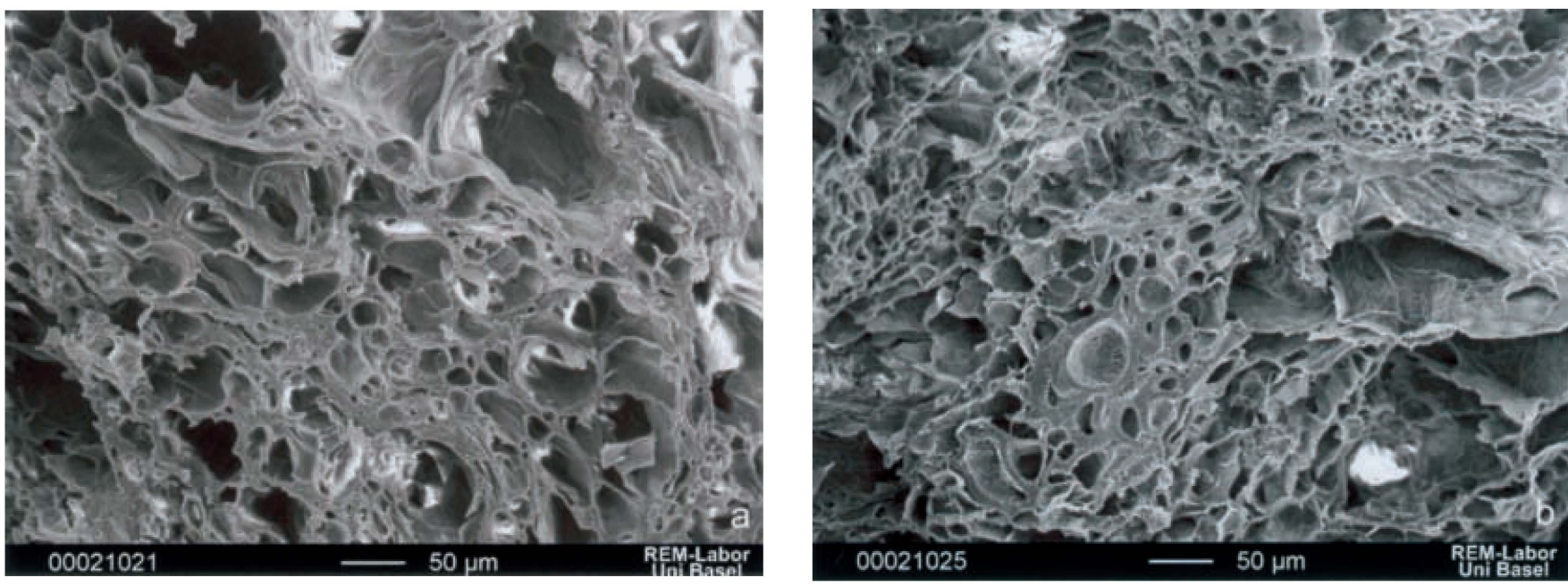

Fig. 6. SEM photographs of the cross-section of the pericarp of pomegranate: a: Roman specimen from phase 2 , b: artificially carbonised specimen. Photographs by Labor für Rasterelektronenmikroskopie, Basel University

In order to find out how high the temperatures in the soil could be raised during a fire on the surface, G. Suter (Swiss Safety Institute) carried out model calculations (see results). The model is based on a complete burn-out of a wooden building (dimensions $14 \times 17 \mathrm{~m}$ ). The totally available thermal energy is calculated based on the combustion energy of the walls, floors and roof as well as wooden furniture.

For the heat transfer in the soil typical values were assumed. The model is conservative in the sense that if the parameters chosen lead rather to higher temperatures than those to be expected in reality. Some of the building parameters come from the hypothetical reconstruction of the building by the excavator A. Hagendorn (see Hagendorn in press and results).

The carbonisation experiments were carried out at the EMPA at St. Gallen by A. Ritter. A first series of experiments aimed simply to carbonise whole pomegranates. They were put in a muffle oven for $1-4$ hours and exposed to temperatures of $300-400^{\circ} \mathrm{C}$. Two specimens were carbonised at each temperature, one of which was in a fresh state, and the other was dried for several hours and had a hard pericarp.

Based on the results of $G$. Suter we made a second experiment with the following parameters: slow heating up of the oven for 8 hours, steady temperature of $150^{\circ} \mathrm{C}$ resp. of $200^{\circ} \mathrm{C}$ for 20 hours, followed by slow cooling of the oven for 10 hours.

Then we used a "crush test" to test how easily whole carbonised pomegranates are broken, because, in the Roman material, only fragments of the pericarp were found, and the seeds also were present mostly as fragments. The crush test should simulate the levelling activities after the catastrophic burning down of the building. It was performed in a plastic box of dimensions of $36 \times 26 \mathrm{~cm}$. We dropped a bag with $1000 \mathrm{~g}$ of sand and gravel from a height of $60 \mathrm{~cm}$ onto the pomegranate. Then, the broken pomegranates were pounded 15 times with a wooden pestle, applying minor force. Every stage of the procedure was documented by a photograph.

\section{Results}

The remains of edible useful plants in the Augustan phases HP 2 - 4 (Table 1)

In the structures of the Augustan phases HP 2 - 4, a total of about 14,000 carbonised seeds from 33 samples were recovered. From phase 5 onwards, mainly mineralised mate- rial from latrines was found (also about 14,000 items). We concentrate here on the remains of the Augustan phases, and so the latter will not be discussed in detail.

Some of the samples, mainly from phase 2 , had a very high density of carbonised seeds and fruit remains. Some of the barrels especially furnished the highest densities of plant remains of all 59 samples from the excavation. The most frequent, identifiable plant remains in phase 2 were seeds of Punica granatum L. (pomegranates) of which 425 seeds and seed-fragments were found (Fig. 5a, Table 1).

However, the greatest amounts of carbonised plant material - besides the dominant charcoal - were more or less amorphous objects with a fairly distinct cell structure. Amongst these were about 1000 fragments of a plant tissue, about $1.5-2 \mathrm{~mm}$ thick on average, and with a rather dense structure (Fig. 5b); this group was clearly distinguishable from the over 4000 other remains of, probably, fruit flesh (Table 1). Because a large number of pomegranate seeds were identified these remains were compared with artificially carbonised pomegranate pericarp and they showed a strong similarity. SEM photographs confirm the identification as pericarp of pomegranates (Fig. 6).

All the pomegranate remains were concentrated in the bottom layers of some of the barrels (Fig. 7). This leads us to suggest that pomegranates were primarily kept in the barrels. Beside those in the barrels, pomegranate remains were otherwise very rare (Table 1); only five seeds were found in other samples of phase 2 , three in phase 3 and nine in phase 4 . Securely identified pericarp fragments were restricted to the barrels, and only a few possible fragments were found outside the barrels and in phases 3 and 4.

Beside pomegranates, many other edible (useful) plants were found in phase 2, but also in phases 3 and 4 (Table 1). It is worth mentioning that other introduced species like olive, walnut, pine, pistacio, peach, cherry and probably also date were present. For Augustan times this is a very rich spectrum of edible plants, reminiscent of the spectra of early legionary camps like Oberaden (Kučan 1992) or Neuss (Knörzer 1970; see discussion and conclusions). 


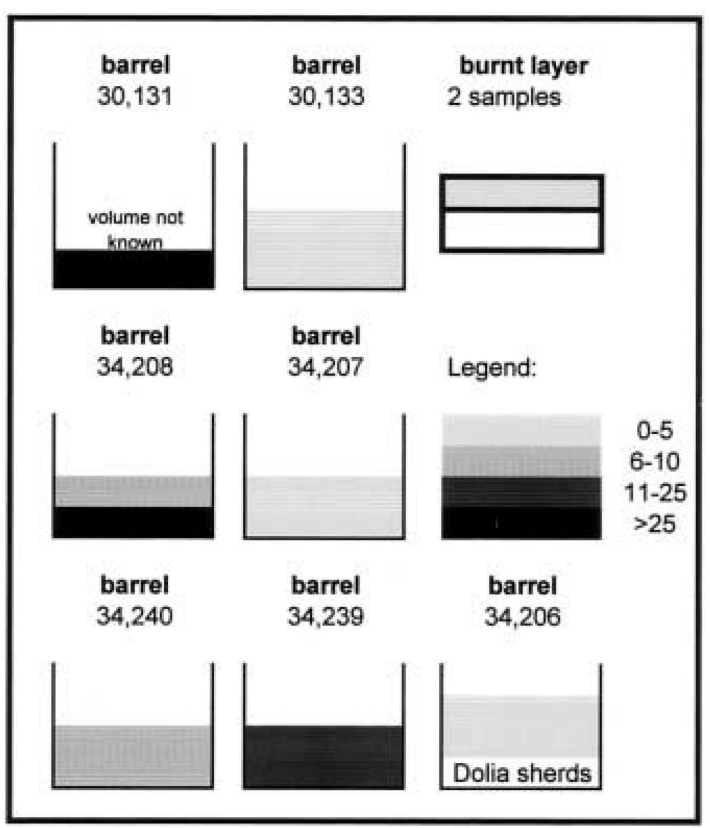

Fig. 7. Density of pomegranate remains in the barrels of phase HP 2, compared with the densities in the burnt layer, southwards of the barrels (see Fig. 3)

\section{Results of the model and the experiments}

The main result of the fire model is that temperatures reached in the soil at a depth of $50-60 \mathrm{~cm}$ hardly exceed $150-200^{\circ} \mathrm{C}$, but they last for many hours (Fig. 8). Therefore, the carbonisation process must have taken place over a long time, but at rather low temperatures.

The first series of carbonisation experiments - before the fire-modelling - produced fully carbonised pomegranates at a temperature of $400^{\circ} \mathrm{C}$ within $1-2$ hours. How-

\section{Temperatures in soil}

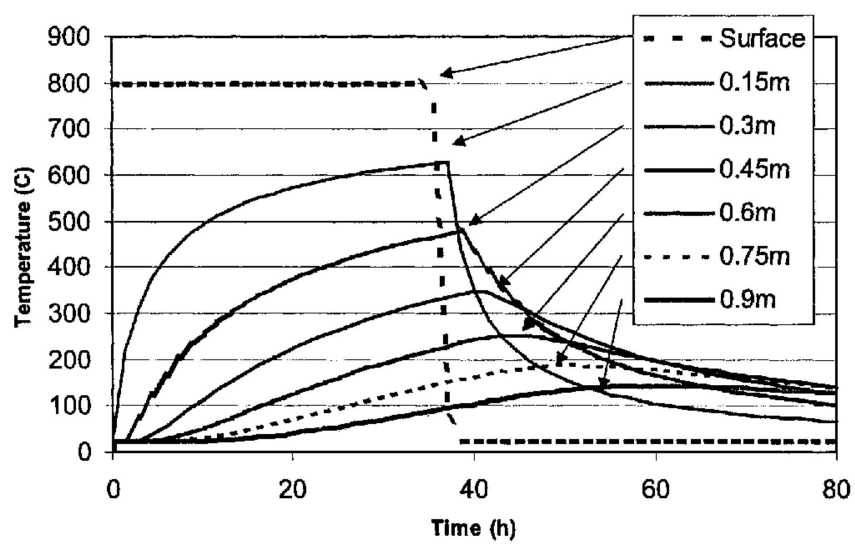

Fig. 8. Model of the temperature pattern in different soil depths during the burning of the building of HP 2 (see Table 2 for parameters). The modeling is based on the properties of gravel. If we assume that the barrels were completely filled, a very similar temperature pattern can be assumed. However, if the barrels were only partly filled, we can suppose slightly higher temperatures inside (G. Suter, Swiss Safety Institute, Basel) ever, the pericarp was rather badly destroyed. The remnants of the pericarp and the inner parts with the seeds easily broke into small fragments with the crush test, mostly after the first falling event. However, the seeds were still covered by the remains of the fleshy and juicy parts of the aril (succulent covering around the seed), and so they did not closely resemble the Roman specimens.

The second, and much more reliable, experiment produced totally carbonised pomegranates with a well preserved pericarp (Figs. 9a,b). The soft and juicy parts of the fruit, the arils around the seeds, boiled away. They were visible as an amorphous black mass surrounding the fruit (Figs. 9a,b). Both fruits crushed easily after only the first falling event (Figs. 10a,b). After smashing the fragments with the wooden pestle for 15 times, there were a lot of rather small pericarp fragments and whole seeds, but also some seed fragments (Figs. 11a,b).

The fragments of the pericarp were better preserved for the specimen carbonised at $150^{\circ} \mathrm{C}$ (Figs. 9a, 10a and 11a), and they had a similar consistency to the Roman specimens found at the site (Figs. 12a,b). In contrast, the seeds of the specimens carbonised at $200^{\circ} \mathrm{C}$ (Figs. 9b, 10b and $11 \mathrm{~b})$ looked very similar, or almost identical to the Roman specimens (Figs. 13a,b). The soft parts of the arils were more or less totally burnt away, and the testa (outer seed coat) itself was visible in most of the specimens.

\section{Discussion}

\section{Distribution and origin of the pomegranate}

The pomegranate is a large shrub or a tree with big red flowers. It is widespread around the whole Mediterranean basin. It grows best in a semi-arid, mild-temperate to subtropical climate. A wet climate is unfavourable. Temperatures below $-10^{\circ} \mathrm{C}$ seriously damage the tree.

The present distribution area of the pomegranate is strongly influenced by humans. The original area was much smaller than it is today. According to Zohary and Hopf (2000, pp $170 \mathrm{ff}$.) the wild form is widespread in the regions south of the Caspian Sea, in north-eastern Turkey and in the southern Balkans (Albania, Montenegro). The tree was probably cultivated first in western Asia, because the earliest finds, from the early Bronze Age, come from that region (Arad: Hopf 1978, Jericho: Hopf 1983). According to Muthmann (1982), the pomegranate spread westwards to Syria, Palestine and Mesopotamia. In Mesopotamia, the pomegranate is mentioned in cuneiform scripts from the second half of the 3rd millennium B.C. (after Postgate 1987, from Zohary and Hopf 2000). The pomegranate was probably brought to Egypt from here around 1500 B.C., through the campaigns of Thutmosis III. However, there are some earlier finds of pomegranates in Egypt, dating from the 12th dynasty (early 2nd millennium B.C.; Schweinfurth 1891). Another early centre of dispersal of the pomegranate was probably Cyprus during the 3rd millennium B.C. Pomegranates probably reached the western Mediterranean and northwestern parts of Africa from here, through the Phoenicians (by the sea route). Crete was also reached from Cyprus, and finally around 900 B.C. the pomegranate reached Greece. From here the pomegranate came finally to Italy where it is found from the Archaic Period (6th/5th cent. B.C., Ciaraldi 1999). 
Table 2. Parameters for the fire model (G. Suter), * = calculated based on model parameters

\begin{tabular}{|c|c|c|}
\hline Model Parameters & Typical range & $\begin{array}{l}\text { Values for the model } \\
\text { (Fig. 8) }\end{array}$ \\
\hline
\end{tabular}

\begin{tabular}{|c|c|c|c|c|}
\hline $\begin{array}{l}\text { Heat conductivity of } \\
\text { material above fruit }\end{array}$ & 1.4 & 2.1 & 2.1 & $\mathrm{~W} / \mathrm{mK}$ \\
\hline $\begin{array}{l}\text { Heat capacity of } \\
\text { material above fruit }\end{array}$ & 800 & 2500 & 1000 & $\mathrm{~J} / \mathrm{kg}^{*} \mathrm{~K}$ \\
\hline $\begin{array}{l}\text { Density of material } \\
\text { above fruit }\end{array}$ & 600 & 2500 & 2000 & $\mathrm{~kg} / \mathrm{m}^{3}$ \\
\hline Ambient temperature & -5 & 30 & 25 & ${ }^{\circ} \mathrm{C}$ \\
\hline $\begin{array}{l}\text { Surface temperature } \\
\text { below fire }\end{array}$ & 600 & 1000 & 800 & ${ }^{\circ} \mathrm{C}$ \\
\hline $\begin{array}{l}\text { Heat flow into soil/ } \\
\text { total heat production }\end{array}$ & - & - & 10 & $\%$ \\
\hline \multicolumn{5}{|l|}{ House } \\
\hline$\overline{\text { Length }}$ & - & - & 17 & $\mathrm{~m}$ \\
\hline Width & - & - & 12 & $\mathrm{~m}$ \\
\hline Height & - & - & 5 & $\mathrm{~m}$ \\
\hline Dividing walls (lengths) & - & - & 1 & \\
\hline Dividing floors (height) & - & - & 1 & \\
\hline Dividing walls (width) & - & . & 3 & \\
\hline Thickness of walls & - & - & 5 & $\mathrm{~cm}$ \\
\hline $\begin{array}{l}\text { Factor for wooden } \\
\text { furniture }\end{array}$ & - & - & 1.5 & \\
\hline Density (wood) & - & - & 600 & $\mathrm{~kg} / \mathrm{m}^{3}$ \\
\hline $\begin{array}{l}\text { Heat of combustion } \\
\text { (wood) }\end{array}$ & - & - & 20 & $\mathrm{MJ} / \mathrm{kg}$ \\
\hline Total volume of wood* & - & - & 91.275 & \\
\hline Fire load per $\mathrm{m}^{2 *}$ & - & - & 5369.11765 & $\mathrm{MJ} / \mathrm{m}^{2}$ \\
\hline $\begin{array}{l}\text { Maximum burning time } \\
\text { (approx.)* }\end{array}$ & - & - & 35 & $\mathrm{~h}$ \\
\hline
\end{tabular}

Other archaeological records of pomegranates

The finds of pomegranates in Vindonissa are already in themselves unique. The large quantities found there are outstanding. Until now, there was no direct proof of pomegranates north of the Alps in Roman times. There are some Terracottae from Nida-Heddernheim (Germany; Rüger 1980 ) but no plant remains. The earliest come from medieval latrines, one from Konstanz (Germany, A.D. 13th cent., Küster 1988) and one from Oostende/Raversijde (Belgium, A.D. 15th cent.; Pieters et al. 1995). Most of prehistoric or classical finds come from the Near East, Egypt and the eastern Mediterranean region (see Hopf 1978, Hopf 1983; Schweinfurth 1891; Hepper 1990; Hjelmqvist 1979; Kroll 1982; Kučan 1995). Recently, some pomegranates were also detected in more western parts of the Mediterranean: in southern Italy in a sanctuary of Demeter and Persephone in Oria, Apulia, from Archaic (6th/5th cent. B.C.) and Hellenistic (4th/3rd cent. B.C.) times (Ciaraldi 1999). These are the oldest finds in Italy. Most recently, uncarbonised pomegranates were recovered from the Greek colony of Massilia, in southern France (5th cent. B.C., Bouby and Marinval 2000). The cultivation of the pomegranate had probably reached the western Mediterranean by this time.

Roman finds of pomegranates are known only from southern Italy! They come from the sites near Vesuvius, from Pompeii and villae nearby (Meyer 1988; Ciaraldi
1997; Ciaraldi and Richardson 2000; Ricciardi and Aprile 1988). They begin in the 2 nd cent. B.C., but the majority comes from Flavian times, preserved by the eruption of Vesuvius in A.D. 79. In the villa of L. Crassus Tertius in Oplontis, a pit with thousands of pericarp fragments was found. They come from unripe pomegranates and were probably used for tanning (see Meyer 1988, p. 208). These are the only finds of pericarp known until now. Finds of pomegranates are also rare in Italy; however, it is known from written sources, that pomegranates were highly regarded in Rome. Pomegranates are also very common as pictures or reliefs, for example in Pompeii (Muthmann 1982; Fig. 14). To conclude, pomegranates also seem to have been rather a luxury fruit in Italy.

\section{Use of pomegranates}

According to classical authors, there were already several varieties of pomegranates in Roman times (André 1998). Written sources and pictures suggest that the use of the pomegranate was diverse. There are many references to the cultivation, and above all the preservation of pomegranate by the classical authors (see compilation by André 1998). First of all, pomegranates were a highly esteemed edible fruit. In cookbooks for the upper class, like Apicius, pomegranates are mentioned regularly. In the "Cena of Trimalchio" (Petronius 31, 11, A.D. 1st cent.) "Syrian plums with pomegranate seeds" are mentioned. This suggests that pomegranate was a rather luxurious dish. The rich people liked mostly imported fruits from Carthage, but also from some regions of Greece (see Muthmann 1982, footnote 327 ). In addition, a fruit juice (today called "grenadine") was made from pomegranates. Ciaraldi (1999) suggests that pomegranates were of great importance as sources for juice making because, before the introduction of citrus fruits in the early middle ages (Zohary and Hopf 2000, pp $184 \mathrm{f}$.), pomegranate was the only reliable source of juice. The juice can also be used to marinade meat, and the proteolytic enzymes it contains preserve the meat. Ciaraldi (1999) mentions the making of jam from pomegranates. Dried seeds were apparently an interesting alternative to dried raisins in cakes. They can also be used as a spice. In Roman times written sources also mention drying of the seeds to be eaten as a snack (homepage Graz University www-ang.kfunigraz.ac.at/ $\sim$ katzer/germ/). There are also several medicinal uses (see homepage www.naturopathic.org and Ciaraldi 2000). The pericarp of unripe fruits can be used for tanning, because its high content of tannin (mentioned by Plinius; see above, pit filled with unripe pomegranates in the Oplontis Villa). The pericarp of pomegranates can also be used for dying; the colour produced without chemical additions is lemon-yellow or reddish-brown (Roth et al. 1992; Polunin 1971). Above all, the pomegranate has a great symbolic significance (Dierbach 1833). It is an attribute of Hera or Juno; classical statues of Juno always have a pomegranate in her hand. Juno was a goddess of marriage and fertility. Therefore, the pomegranate played a role during wedding ceremonies. Muthmann (1982, pp $102 \mathrm{ff}$.) describes several rites during which the gods and goddesses are mentioned in combination with pomegranates. 

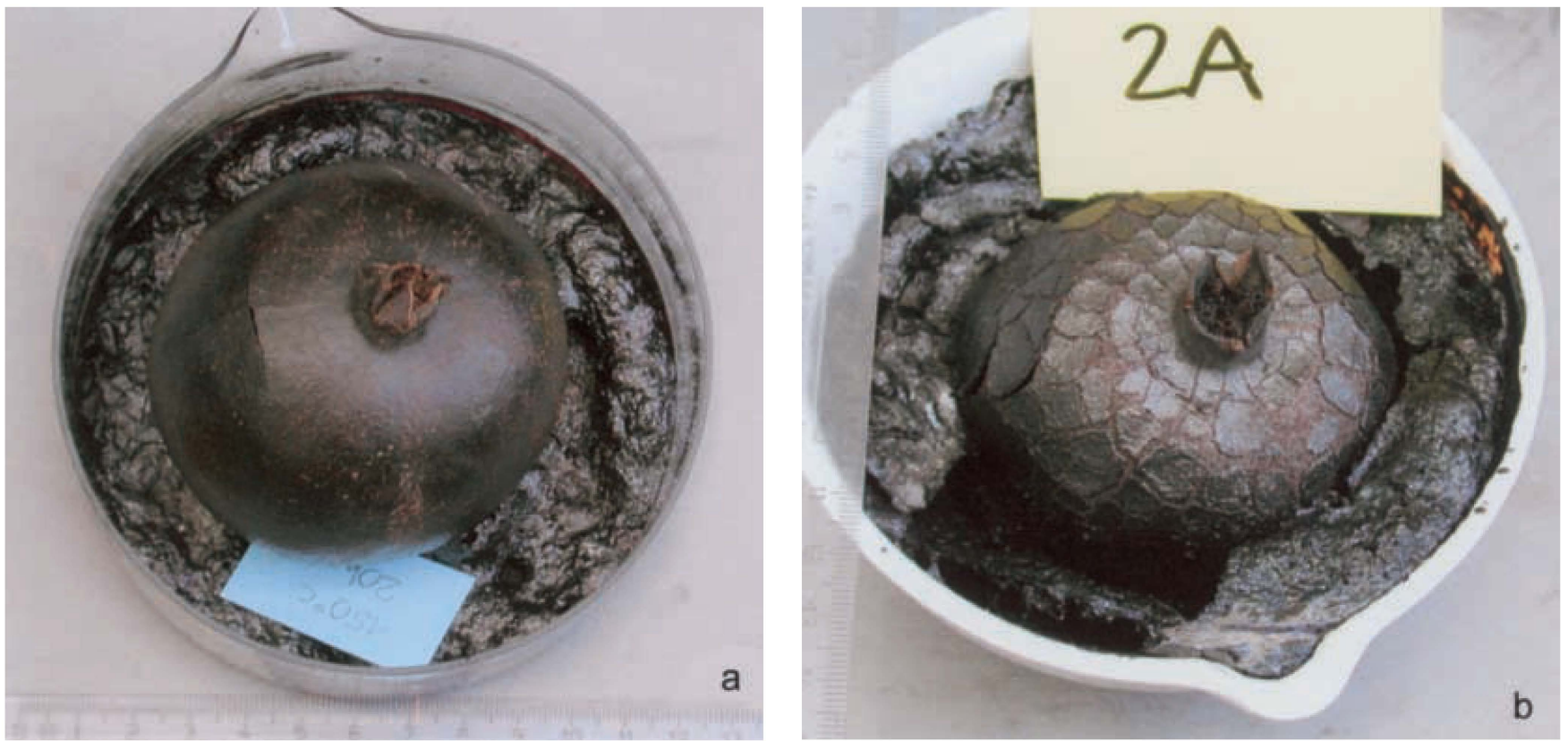

Fig. 9. a: artificially carbonised pomegranate $\left(150^{\circ} \mathrm{C}, 20 \mathrm{~h}\right)$, b: artificially carbonised pomegranate $\left(200^{\circ} \mathrm{C}, 20 \mathrm{~h}\right)$. Photographs by S. Jacomet

Time of ripening, storage, durability and transport of pomegranates

The time of ripening begins in autumn (Ciaraldi 1999) and lasts for several months. The fresh fruits cannot be kept well for a longer time (several weeks). The biggest problem is that they are highly sensitive to pressure. If they have damaged parts they begin to rot very quickly. Therefore it was very important to pack them very well before transport so that they could not get damaged. In classical texts there are several descriptions of the conservation and storage of pomegranates (André 1998, pp $73 \mathrm{ff}$. according to several classical texts like Plinus, Varro and others). In rural farmsteads special fruit-rooms were installed (pomarium) which could be equipped very luxuriously (for example with a lining of marble) to preserve the freshness of the fruit. The fruits were put on shelves, which were covered with straw or wood chips. The fruits should not touch each other. It is also known, that the fruits were covered by a layer of plaster, wax or clay, which prevent evaporation. Alternatively, they were put for a very short time into hot, salty water which caused the pericarp to become hard. Our own experiences show that when the pericarp is dried, pomegranates can last for several weeks without damage. However, the most common method of conservation was underground storage in closed vessels which were pitched and hermetically sealed. This is strongly reminiscent of the carbonised barrels of the "Breite" excavation.

To conclude, it seems that pomegranates were rather a luxury fruit, used mainly by the upper class in the Roman motherland. Conservation and transport were a problem because of their high sensitivity to pressure.
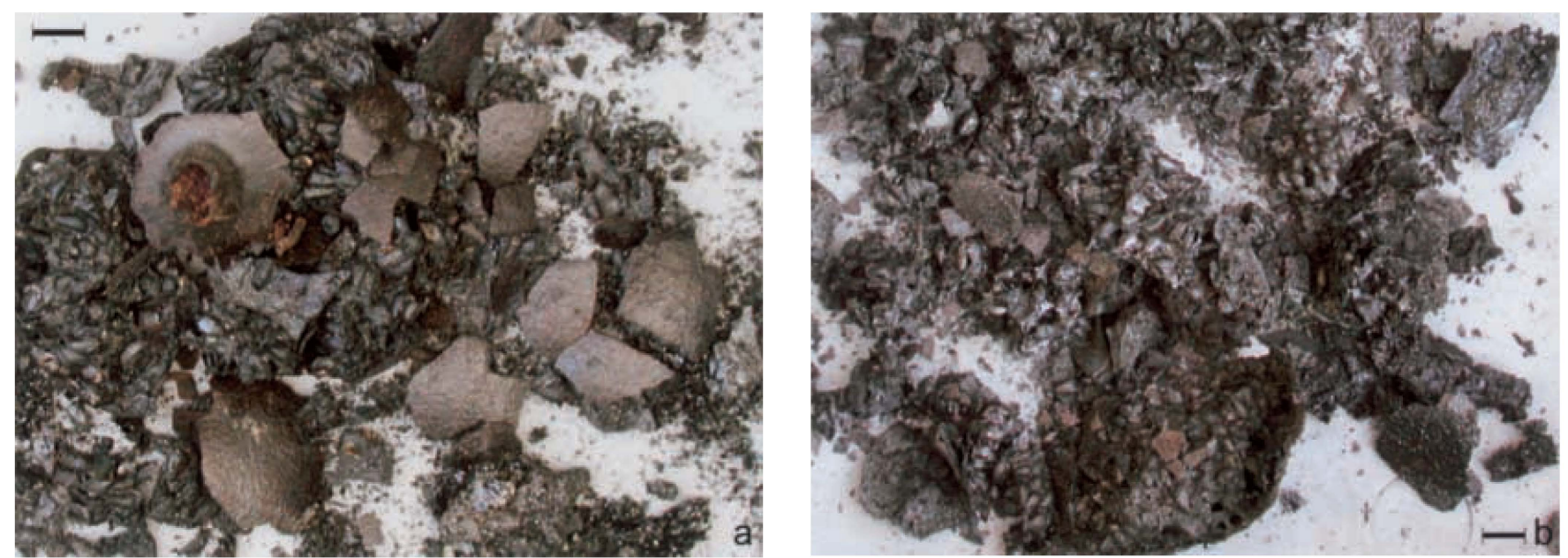

Fig. 10. a: artificially carbonised pomegranate $\left(150^{\circ} \mathrm{C}, 20 \mathrm{~h}\right)$ after the first falling event of the crush-test, b: artificially carbonised pomegranate $\left(200^{\circ} \mathrm{C}, 20 \mathrm{~h}\right)$ after the first falling event of the crush-test. Scale $=1 \mathrm{~cm}$. Photographs by S. Jacomet 

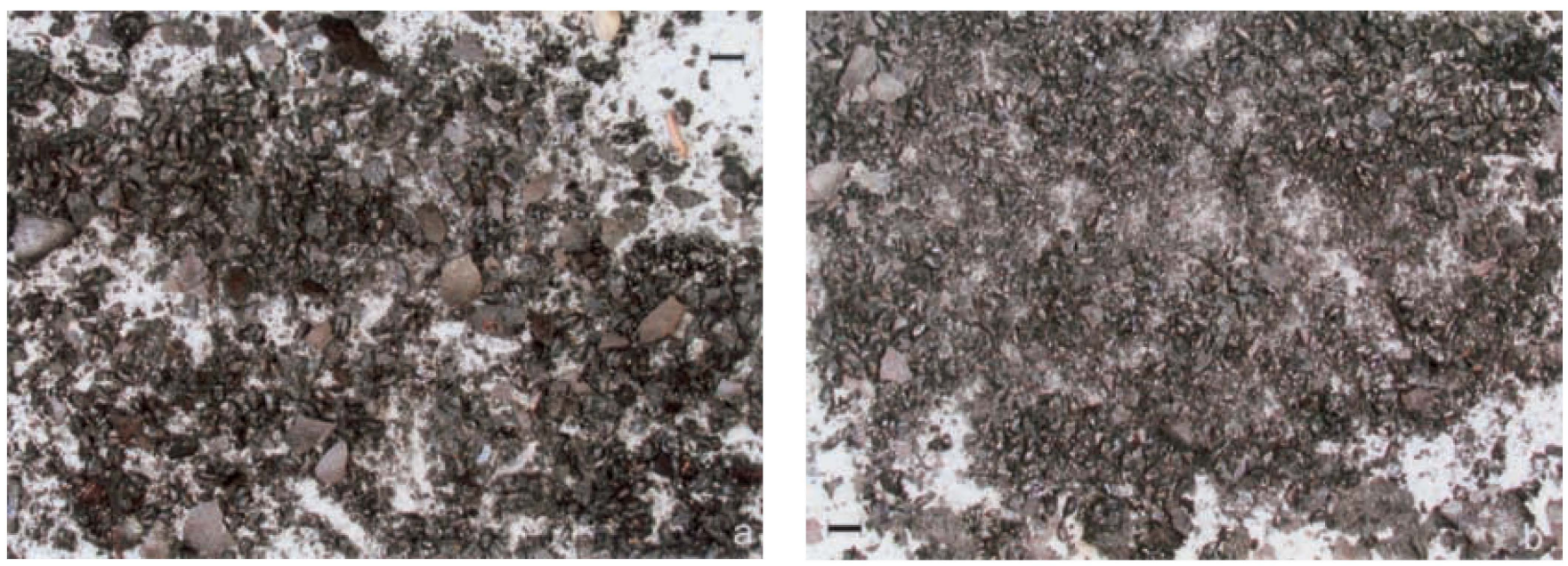

Fig. 11. a: artificially carbonised pomegranate $\left(150^{\circ} \mathrm{C}, 20 \mathrm{~h}\right)$ after treatment with the wooden pestle, b: artificially carbonised pomegranate $\left(200^{\circ} \mathrm{C}, 20 \mathrm{~h}\right)$ after treatment with the wooden pestle. Scale $=1 \mathrm{~cm}$. Photographs by S. Jacomet

\section{Storage of the pomegranates in Vindonissa}

Because pomegranates were concentrated in the bottom layers of two barrels (Fig. 7) we made the hypothesis that they were stored in the barrels. On the basis of information from the classical authors (Andre 1998), this hypothesis seems to be reliable. The other remains found in the barrels are more likely to be secondary fills, because they are also widespread in the burnt layers, in contrast to the pomegranates. In addition, they are not concentrated in the bottom layers of the barrels (for more detailed discussion see in Hagendorn et al., in press and Jacomet, in press). They were mixed together during the intense levelling activities after the fire, which also lead to the spread of fragments from the same ceramic vessel over the whole area.

From the experiments it also seems very probable that whole pomegranates were burnt in situ in the barrels. They were most probably exposed to rather low temperatures, probably not very much higher than $150^{\circ} \mathrm{C}$, but for a long time (more than $20 \mathrm{~h}$ ). Therefore they carbonised slowly, with a very limited supply of oxygen. The soft and juicy parts boiled away more or less totally, leaving seeds without visible arils as shown in the experiment. At the end of the experiment the burnt soft parts formed an amorphous mass, and a similar product probably contributed to the "fatty" consistency of the carbonised bottom layers of the barrels observed during the excavation (Hagendorn et al., in press). The high degree of fragmentation of the pericarp was easily reproduceable with our experimental methods. It is likely that the levelling activities after the burning down of the building in the Roman period produced a greater degree of destruction.

What type of settlement was Vindonissa in Augustan times?

It is highly disputed whether the pre-legionary phases in Vindonissa were influenced by the Roman army or were of a more civil character. To contribute to this discussion from the archacobotanical point of view, a compilation of the useful plant spectra of 49 early Roman sites (including Vindonissa-Breite HP 2-5) from Europe north of the Alps was made (Table 3). These sites are situated in Switzerland, Germany, Belgium, the Netherlands and France. Here we will only look at the useful plants which were introduced by the Romans, at least in any large quantities, and which are therefore absent from or only present in very small quantities at Iron Age sites. Only figs, grape, coriander, celery and dill were found at very few sites like Hochdorf (Stika 1999), Bibracte (Mont Beuvray; Wiethold 1993, 2000) or Basel-Gasfabrik (Basel Lab, unpublished). To summarise, such useful plants are not present regularly and never in large quantities in late Iron Age contexts. At the present state of research it can be concluded that the Romans introduced them on a larger scale.

For the compilation, only early Roman sites were considered which should be datable as precisely as possible (not later than Claudian-Neronian, A.D. 40 - 70). For each site, we tried to treat all datable contexts separately. Most of the sites considered were inside the "Imperium Romanum"; sites outside were taken into consideration only when the presence of the Romans was proven by finds of ceramics (for example Bentumersiel in northwestern Germany, Behre 1977). As far as possible from information in the publications, we considered the location of the

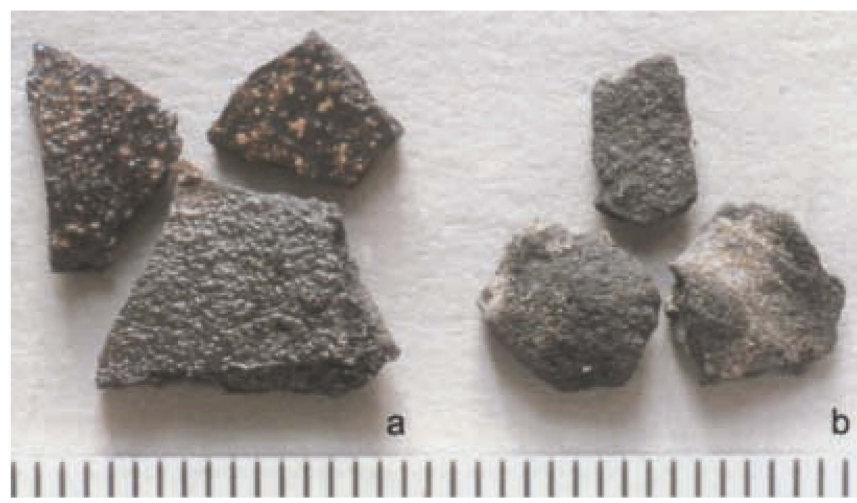

Fig. 12. Pericarp fragments of pomegranate a: artificially carbonised $\left(150^{\circ} \mathrm{C}, 20 \mathrm{~h}\right)$, b: some early Roman specimens from the barrels of phase 2. Photographs by U. M. Weber, Larix-Consult, Basel 


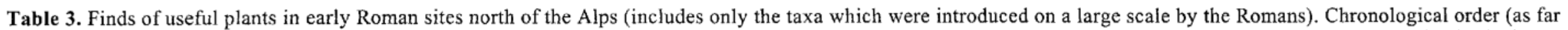

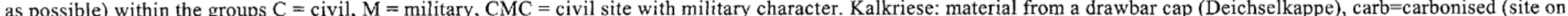

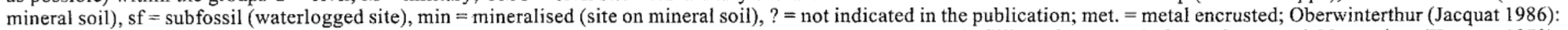

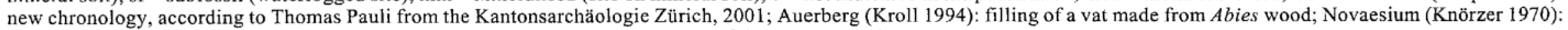
sites included only if securely dated to the Augustan period and the first quarter of the 1st cent. A.D.

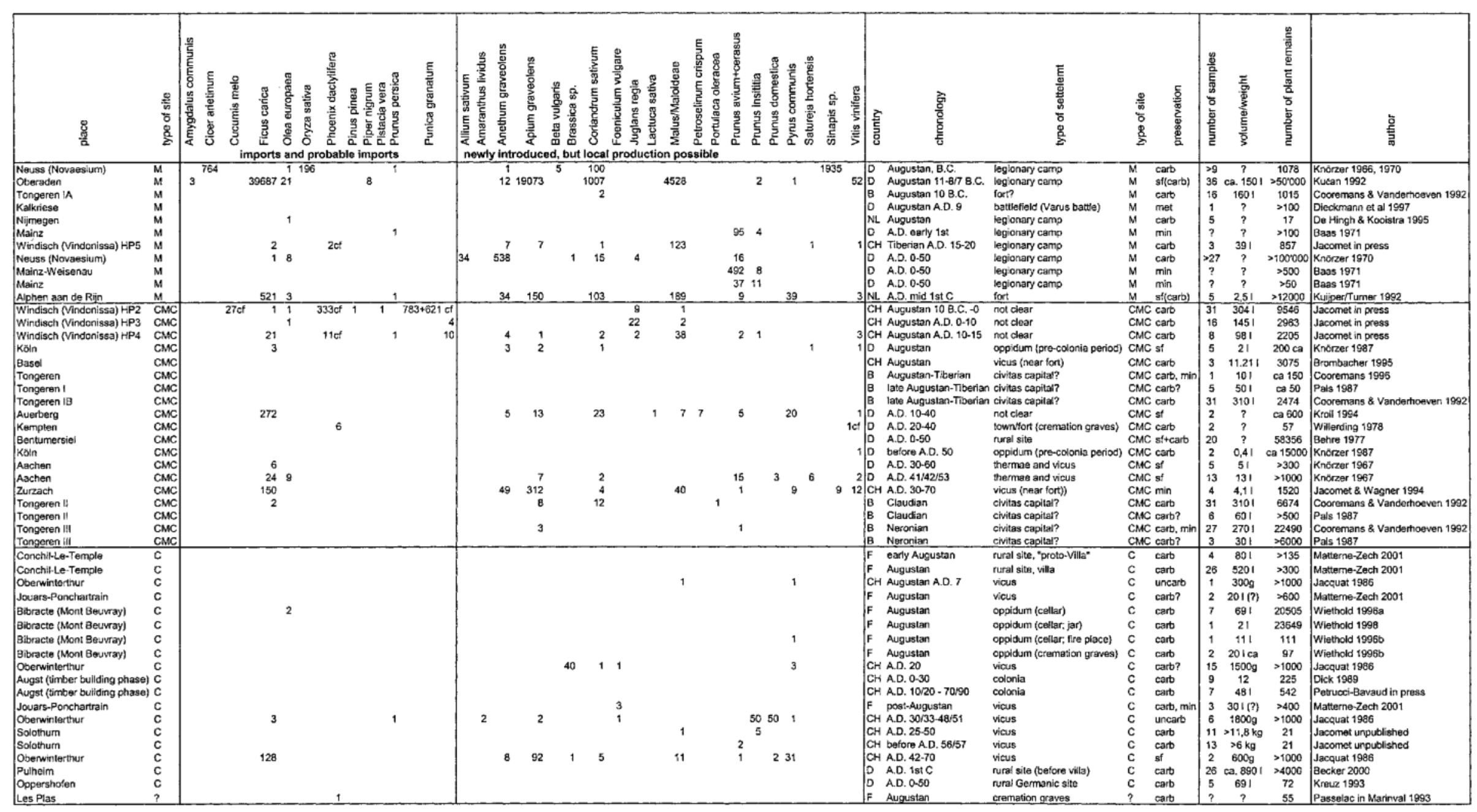




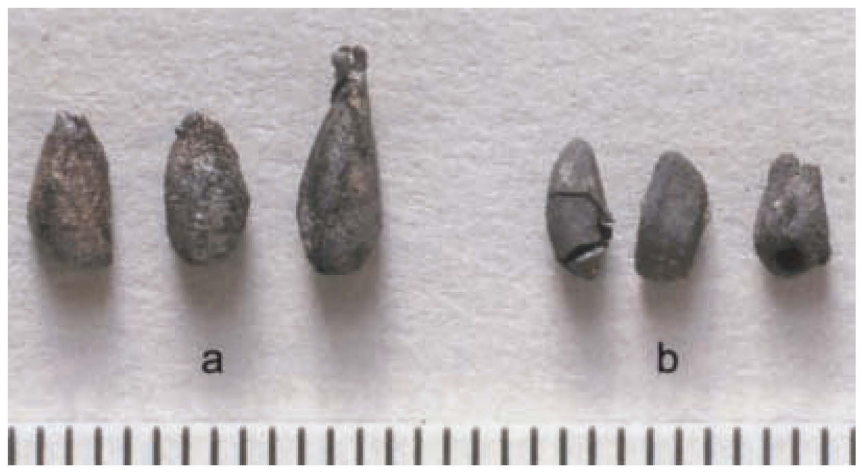

Fig. 13. Seeds of pomegranate: a: artificially carbonised $\left(200^{\circ}\right.$ $\mathrm{C}, 20 \mathrm{~h}$ ), b: some early Roman specimens from the barrels of phase 2. Photographs by U. M. Weber, Larix-Consult, Basel

investigated structures within the sites (for example, was a latrine used by a centurio like in Alphen/NL (Kuijper and Turner 1992) or by soldiers?).

The definition of a site as "military" or "civil" was very important for comparisons with the Vindonissa-Breite site. Eleven of the sites considered here are clearly of a military character; these are for example the big legionary camps at the Rhine frontier like Mainz (Mogontiacum), Neuss (Novaesium), and Nijmegen (Noviomagus) but also Oberaden (bibliography see Table 3 ); they all begin in Augustan times. 18 of the sites are almost certainly of a civil character. These are coloniae (towns) like Augusta Raurica in northwest Switzerland, or some vici which are not connected with forts such as in Switzerland, Solothurn (Salodurum) and Oberwinterthur (Vitudurum), or in northern France, Jouars-Ponchartrain (=Diodurum; for the bibliography, see Table 3). Some rural sites, where later mostly villae rusticae were built, were also considered.

In some cases it was not clear whether a site had a military or a civil character. For that reason we created the term "civil site with a military context" $(\mathrm{cmc})$. This applies to a group of 16 sites (without Vindonissa-Breite HP 2 4), which are of a civil character. But it is known from the archaeological record that there was a strong presence of military personnel at the site, as for example at the thermae of Aachen, which were visited by large numbers of soldiers of the lower Rhine army. One site could not be grouped.

Because the state of investigation of the sites is extremely heterogeneous it is not possible to compare the numbers of the plant remains recovered (see Table 3 ). In addition, the preservation of the structures is not the same (some are waterlogged, some not; table 3). However, in every group of sites (civil, military or civil but with a military character) every type of preservation is present. Therefore, some trends can be seen by analysing the spectra of useful plants, but mainly the presence or absence of taxa has to be considered.

The plants introduced by the Romans can be divided into two groups. 12 taxa are of an "exotic" character: it is not possible to grow them north of the Alps, or at least not easily, for climatic reasons (pomegranate, pepper, date, fig etc.). Twenty taxa can be grown locally, vegetable plants (celery, chard), spices (coriander, dill etc.), nuts (walnut) and fruit trees (cherry, plum etc.). Fruits of this latter group were probably imported too in the earliest phases after the Roman conquest.
The group "exotic" taxa is present at 16 of the 49 sites (Table 3 ). They are clearly concentrated on military sites (in 7 of the 11 sites present). In this group, often several "exotic" taxa are present together, such as rice, peach, olive and chickpea in the early Augustan features ("Fundstelle 76") in the legionary camp of Novaesium (Knörzer 1970) and figs, pepper, olives and almonds in the early Augustan legionary camp of Oberaden (Kučan 1992). In the "civil sites with a military context" group there are "exotic" plants at 7 of the 16 sites, but at six of these sites only one taxon is present. At five sites this is fig, at one it is olive. Only at Aachen-Hof, Schnitt 28 (Knörzer 1967), are two taxa present (fig, olive). Finally, of the 18 civil sites, "exotic" plants are present at only three: fig and peach in two different phases at the vicus Vitudurum (Oberwinterthur; Jacquat 1986) and two olive stones in Bibracte (Pâture du Couvent; Wiethold 1996b).

If we have a look at the second group of plants introduced by the Romans, there is also a clear concentration on military sites; taxa of this group are present at 9 of the 11 sites. Also here, most of the finds come from the big legionary camps. Celery, dill, coriander, apples, cherries and plums were the most important useful plant taxa. In the group "civil sites with a military context", taxa of this group are present in 8 of the 16 sites. 5 to 6 taxa were found together at the Auerberg (Kroll 1994), Cologne (Knörzer 1987), Aachen (Knörzer 1967) and Zurzach (Jacomet and Wagner 1994); these are places with a strong military presence nearby or even at the site. In civil sites this group of taxa is not frequent, they occur in 8 of the 18 sites; more than two taxa were found only at Oberwinterthur in different sites (Jacquat 1986).

Above all the group of "exotic" taxa strongly concentrates on military sites or sites strongly influenced by military activities. This is also the case for most places of the second group. However, only in very rare cases it is possible to determine which grades of the army really were eating the introduced plants. There are two examples where an investigated structure can be connected with a special person or group of people:

- Latrine $47 \mathrm{~b}$ from the legionary camp of Oberaden in northern Germany (Kučan 1992), dated to Augustan times, belonged to the buildings of centurions (officers). From the total of 11 taxa found there 4 were sure imports, including almonds, olives and pepper. Grape and other taxa of the second group found there were probably also imported. In most of the other samples in Oberaden (in total from 11 features) only 2 - 3 imported taxa were present (celery, coriander and fig). However, there are two other pits with pepper, but for these the exact contexts are unknown. Nevertheless, it seems clear that pepper, olives and almonds were more luxuries, whereas figs or coriander had a much more "ordinary" status. Therefore, it is not surprising that the latter group is present at many sites (Table 3 ).

- in the latrine of a centurion, in the castellum of Alphen in the Netherlands (Kuijper and Turner 1992) olives, celery, dill, coriander and cherry were present.

To conclude, Roman officers, at least in the bigger legionary camps were consuming rare and exotic plants. Foods like figs and coriander were more widespread and were probably also consumed by lower ranks and civilians (see also the compilation by Bakels and Jacomet, in press). 


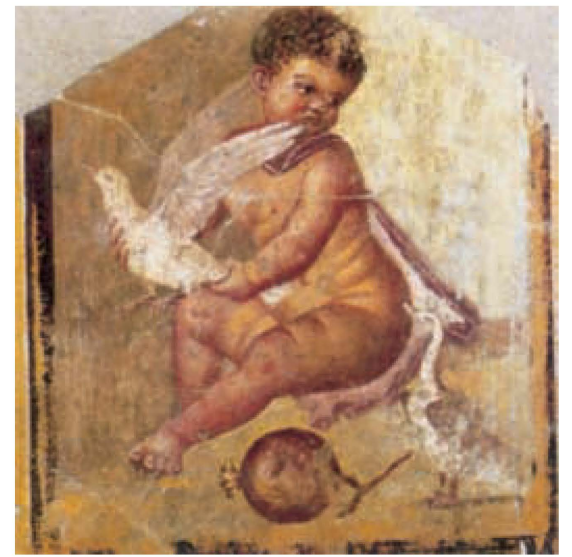

Fig. 14. Wall painting from Pompeii (Casa di Successus) showing a child with a pigeon and a pomegranate. From "Pompeji wiederentdeckt", Antikenmuseum Basel (1994)

\section{Conclusions}

It could be shown by the experiments that most probably whole pomegranates were stored in wooden barrels in Augustan Vindonissa. They were carbonised in situ and highly fragmented during the levelling activities after the fire. But who used the pomegranates, as well as the other stored fruits, wine, olive oil and fish (mackerel)? As the spectra of other early Roman sites show (Table 3), the Roman military played a very decisive role in introducing new plant taxa. Already during the first phases of the Roman conquest large quantities of very "exotic" taxa reached at least the big legionary camps very far away from the Roman "motherland".

In Vindonissa, in the Augustan phases several taxa of imported plants were found (Tables 1, 3). A maximum of seven taxa of "exotic" plants was present in building phase 2 , in the other building phases, 3 and 4, respectively two and four taxa were present. "Exotic" taxa which are normally absent in early Roman contexts were present including pomegranates, pine, pistacio and probably also melon. Also the large quantities of probable dates are almost unique; only a few are known from early Roman contexts from a grave at Kempten (Willerding 1978; Table 3). The rather large quantities of walnut shells in VindonissaBreite are very remarkable, too; until now, only 4 walnut shells from early Roman contexts were known from the legionary camp of Novaesium (Knörzer 1970; Table 3). If we exclude the ca. 40,000 fig seeds from Oberaden, where waterlogged conditions caused the preservation of a large number of specimens, the largest quantities of imported fruits from early Roman contexts north of the Alps were found at Vindonissa-Breite (Table 3). If we consider that carbonisation always results in a large loss of information, the amount seems even more extraordinary. Therefore, on the basis of the spectra of useful plants it must be suggested that in early Augustan times there were possible consumers of luxury goods, probably among the higher military ranks at the site itself or nearby.

From the excavated features and the other archaeological finds it would not be possible to conclude a unique importance of the site in Augustan times. The building itself has a Celtic character; however, the amalgamation of several buildings into a complex shows a Roman influence (Hagendorn, in press). The spectrum of coins seems to show a military presence on the site but is not extraordinary (Doppler, in press). The spectrum of metallic objects seems to indicate the presence of military personnel, but also Celtic people at the site (Huber, in press). As expected in this time, there is hardly any glass (Fünfschilling, in press), but compared with other sites in Switzerland of a similar date there are many lamps (Käch, in Hagendorn et al., in press). The spectrum of ceramics includes some rare imported types from Italy; but the majority of the forms are Celtic, indigenous types (MeyerFreuler, in press). In the building, there are many amphorae from the Iberian peninsula present, in which wine, olive oil and fish-sauce were imported (Martin-Kilcher, in press). This and the presence of barrels (some of which were secondarily used as storage vessels) point to a massive import of wine which suggests the presence of military consumers (Hagendorn et al., in press). The presence of Mediterranean mackerel and the bones of songbirds point to Mediterranean food habits (Hüster-Plogmann, in press). The remains of the larger animals point to higher social levels (Pfäffli and Schibler, in press).

To summarize, compared with other sites of the same date there is a suggestion of special, probably upper class people present at or near the site, but the majority of finds points to a more ordinary character. The project clearly shows therefore that archaeobotanical investigations make a serious contribution to the interpretation of the importance of a site. Only in such an interdisciplinary way it is possible to establish the real importance of a site. However, because clearly comparable sites are totally lacking, it is very hard to define the role of the site at the moment.

Acknowledgments. We are very grateful to the canton Aargau and the Chief Archaeologist, Elisabeth Bleuer, for giving us the opportunity to investigate this very interesting site. The Canton Aargau and the Swiss National Foundation for Scientific Research financially supported the project (Project No 1214054040). Helmut Kroll, Wolf-Dieter Becker, Véronique Matterne-Zech and Angela Kreuz provided us with interesting information on recently published or unpublished data. With Angela Kreuz and Julian Wiethold we had very fruitful discussions on the fragmentation of the pomegranates. Thanks also to Urs M. Weber for the macrophotos, and to the SEM team at Basel University. Glynis Jones made big efforts to improve the English text, special thanks to her! Without the excellent collaboration of the whole "Breite" investigation team these interesting results could not have been achieved - thanks to Christine MeyerFreuler, Heide Hüster-Plogmann, Jörg Schibler, Adrian Huber, Hugo Doppler, Sylvia Fünfschilling, Stefanie Martin-Kilcher, Barbara Pfäffli and Daniel Käch.

\section{References}

André J 1998 Essen und Trinken im alten Rom. Reclam, Stuttgart Apicius (1984) Das Kochbuch der Römer. Rezepte aus der Kochkunst des Apicius. Eingeleitet, übersetzt und erläutert von E. Alföldi-Rosenbaum. Artemis, Zürich

Baas J (1971) Pflanzenreste aus römerzeitlichen Siedlungen von Mainz-Weisenau und Mainz-Innenstadt und ihr Zusammenhang mit Pflanzenfunden aus vor- und frühgeschichtlichen Stationen Mitteleuropas. Saalburg-Jahrbuch 28: 61-87 
Baas J (1987) Römerzeitliche Kultur- und Nutzpflanzen aus Windisch, Avenches und Cham in der Schweiz. Saalburg-Jahrbuch 43: 108-111

Bakels CC, Jacomet S (in press) Luxury Foods in Roman period central Europe - Contributions from Archacobotany. In: Veen M van der (ed) Luxury foods. World Archaeology 34/3 (to be published in 2002)

Becker WD (2000) Archäobotanische Untersuchungen zur Ausgrabung Pulheim-Brauweiler. Pulheimer Beiträge zur Geschichte und Heimatkunde 24: 45-55

Behre K-E (1977) Acker, Grünland und natürliche Vegetation während der römischen Kaiserzeit im Gebiet der Marschensiedlung Bentumersiel/Unterems. Probleme der Küstenforschung im südlichen Nordseegebiet 12: 67-84

Binz A, Heitz C (1990) Schul- und Exkursionsflora für die Schweiz (19. edition), Schwabe, Basel

Bouby L, Marinval P (2000) Ressources végétales à Marseille et dans les sociétés indigènes au Bronze Final et au premier Age du Fer: premiers éléments de comparaison. In: Mailhac et le Premier Age du Fer en Europe occidentale (Hommages à Odette et Jean Taffanel). Actes du Colloque International de Carcassonne, 17-20 Sept. 1997, Monographies d'Archéologie Méditerranéenne 7: 205-214 (Lattes)

Brombacher C (1995) Archäobotanische Untersuchungen von Getreideproben aus dem römischen Vicus Basel-Rittergasse. In: Helmig G, Schön U, Neue Befunde zur antiken Zufahrtsstrasse auf den Basler Münsterhügel. Jahresbericht der Archäologischen Bodenforschung des Kantons Basel-Stadt 1992: 55-56

Ciaraldi M (1999) Food offerings at the Archaic/Hellenistic sanctuary of Demeter and Persephone at Monte Papalucio (Oria, Apulia, Southern Italy). Accordia Research Papers 1997-1998: 75-91

Ciaraldi M (1997) A preliminary report of plant remains from the 1996 Excavation in the House of the Vestals. In: Bon S, Kones R, Kurchin B, Robinson DJ (eds) Anglo-American Pompeii Project 1996, Season Report. Bradford Archaeological Sciences Research 3: 17-23

Ciaraldi M, Richardson J (2000) Food, ritual and rubbish in the making of Pompeii. In: TRAC 99, Proceedings of the ninth annual Theoretical Roman Archaeology Conference, University Durham, April 1999: 74-82 (London)

Cooremans B, Vanderhoeven A (1992) De plantaardige macroresten. In: Het oudheidkundig bodemonderzoek aan de Kielenstraat te Tongeren (prov. Limburg). Archeologie in Vlaanderen 2: $118-126$

Cooremans B (1996) De plantaardige resten. In: Vanderhoeven A, Vynckier G, Ervynck A, Cooremans B, Wouters W, Het oudheidkundig bodemonderzoek aan de Koninksemsteenweg te Tongeren (prov. Limburg). Archaeologie in Vlaanderen 5: 78-84

Desbat A (1997) Letonneau antique: questions techniques et problème d'origine. In: Meeks D, Garcia D (eds) Techniques et économie antiques et médiévales: le temps de l'innovation. Colloque International (C.N.R.S.), Aix-en-Provence, 21.-23. Mai 1996. Errance, Paris, pp 113-120

Dick M (1989) Verkohlte Samen und Früchte aus zwei holzkohlereichen Schichten von Augst (Augusta Rauricorum; Forum und Insula 23). Jahresberichte aus Augst und Kaiseraugst 10: 347-350

Dieckmann U (1998) Paläoökologische Untersuchungen zur Entwicklung von Natur- und Landschaftsgeschichte am Nordrand des Wiehengebirges. Abhandlungen aus dem Westfälischen Museum für Naturkunde 60/4, Münster

Dieckmann U, Speier M, Pott R(1997) Die Kulturpflanzenfunde aus dem Fundgut der archäologischen Ausgrabungen zur VarusSchlacht bei Kalkriese (Lkr. Osnabrück). Natur und Heimat $57 /$ 3: 73-94

Dierbach JH (1833) Flora Mythologica oder Pflanzenkunde in Bezug auf Mythologie und Symbolik der Griechen und Römer. Reprint Sändig, Vaduz 1990
Doppler H (in press) Münzen. In: Hagendorn A, Doppler H, Huber A, Hüster-Plogmann H, Jacomet S, Meyer-Freuler Ch, Pfäffli B, Schibler $J$ (in press) Neue Forschungen zur Frühzeit von Vindonissa und den Lagern der 13. Legion. Veröffentlichungen der Gesellschaft Pro Vindonissa 18

Drack W, Fellmann R (1988) Die Römer in der Schweiz. Theiss, Stuttgart

Fünfschilling $\mathrm{S}$ (in press) Glasfunde. In: Hagendorn A, Doppler $\mathrm{H}$, Huber A, Hüster-Plogmann $\mathrm{H}$, Jacomet $\mathrm{S}$, Meyer-Freuler $\mathrm{Ch}$, Pfäffli B, Schibler J (in press) Neue Forschungen zur Frühzeit von Vindonissa und den Lagern der 13. Legion. Veröffentlichungen der Gesellschaft Pro Vindonissa 18

Furger A, Isler-Kerényi C, Jacomet S, Russenberger Ch, Schibler J (2001) Die Schweiz zur Zeit der Römer. Archäologie und Kulturgeschichte der Schweiz 3. NZZ, Zürich

Hagendorn A, Doppler H, Huber A, Hüster-Plogmann H, Jacomet S, Meyer-Freuler Ch, Pfäffli B, Schibler J (in press) Neue Forschungen zur Frühzeit von Vindonissa und den Lagern der 13. Legion. Veröffentlichungen der Gesellschaft Pro Vindonissa 18

Hepper FN (1990) Pharaoh's flowers. The botanical treasure of Tutankhamun. Her Majesty's Stationary Office, London, $80 \mathrm{pp}$

Hingh AE de, Kooistra LI (1995) Reste von Getreide und anderen Pflanzen. In: Haalebos JK, Bogaers JE, Hoek RGJM, Brinkhuizen DC, Hingh AE de, Kooistra LI, Castra und Canabae. Ausgrabungen auf dem Hunerberg in Nijmegen 1987-1994. Libelli Noviomagenses 3: 103-109

Hjelmqvist $H$ (1979) Some economic plants from the Bronze Age of Cyprus. Studies in Mediterranean Archaeology 45: 110-113

Hopf M (1978) Plant remains, Strata V-I. In: Amiran R (ed) Early Arad I. The Chalcolithic Settlement and Early Bronze Age City. Israel Exploration Society, Jerusalem, pp 64-82

Hopf M (1983) Jericho plant remains (Appendix B). In: Kenyon KM, Holland TA (eds) Excavations at Jericho, vol. 5: The Pottery Phases of the Tell and other finds. British School of Archaeology in Jerusalem, London, pp 576-621

Huber A (in press) Metallfunde. In: Hagendorn A, Doppler H, Huber A, Hüster-Plogmann H, Jacomet S, Meyer-Freuler Ch, Pfäffli B, Schibler $J$ (in press) Neue Forschungen zur Frühzeit von Vindonissa und den Lagern der 13. Legion. Veröffentlichungen der Gesellschaft Pro Vindonissa 18

Hüster-Plogmann $\mathrm{H}$ (in press) Kleintierknochen. In: Hagendorn A, Doppler H, Huber A, Hüster-Plogmann H, Jacomet S, MeyerFreuler Ch, Pfäffli B, Schibler J (in press) Neue For-schungen zur Frühzeit von Vindonissa und den Lagern der 13. Legion. Veröffentlichungen der Gesellschaft Pro Vindonissa 18

Jacomet S, Kreuz A (1999) Archäobotanik. Ulmer, Stuttgart

Jacomet S, Wagner C (1994) Mineralisierte Pflanzenreste aus einer römischen Latrine des Kastell-Vicus (Zurzach). In: Hänggi R, Doswald C, Roth-Rubi K (eds) Die frühen römischen Kastelle und der Kastell-Vicus von Tenedo-Zurzach. Veröffentlichungen der Gesellschaft pro Vindonissa 11: 321-343 (Brugg)

Jacomet $S$ (in press) Archäobotanische Untersuchung der frührömischen Schichten aus der Grabung Vindonissa-Breite. In: Hagendorn A, Doppler H, Huber A, Hüster-Plogmann H, Jacomet $\mathrm{S}$, Meyer-Freuler Ch, Pfäffli B, Schibler J (in press) Neue Forschungen zur Frühzeit von Vindonissa und den Lagern der 13. Legion. Veröffentlichungen der Gesellschaft Pro Vindonissa 18

Jacomet S, Wagner C, Wacker Feigenwinter K, Felice N, Albrecht $H$ (not published) Samen und Früchte aus vorrömischen, römerzeitlichen und mittelalterlichen Ablagerungen in der Altstadt von Solothurn (Schweiz), Areale Vigier und Klosterplatz. Manuscript 1993

Jacquat C (1986) Römerzeitliche Pflanzenfunde aus Oberwinterthur (Kanton Zürich, Schweiz). Berichte Zürcher Denkmalpflege, Monographien 2: 241-264

Käch D (in press) Lampen. In: Hagendorn A, Doppler H, Huber A, Hüster-Plogmann H, Jacomet S, Meyer-Freuler Ch, Pfäffli B, Schibler J (in press) Neue Forschungen zur Frühzeit von Vindonissa und den Lagern der 13. Legion. Veröffentlichungen der Gesellschaft Pro Vindonissa 18 
Knörzer KH (1966) Über römische Importfrüchte in Novaesium (Neuss/Rh.). Bonner Jahrbücher 166: 433-443

Knörzer KH (1967) Römerzeitliche Pflanzenfunde aus Aachen. In: Knörzer KH, Untersuchungen subfossiler pflanzlicher Grossreste im Rheinland. Archaeo-Physika 2: 39-64

Knörzer KH (1970) Römerzeitliche Pflanzenfunde aus Neuss. Novaesium IV, Limesforschungen 10. Mann, Berlin

Knörzer KH (1987) Geschichte der synanthropen Vegetation von Köln. Kölner Jahrbuch für Vor-und Frühgeschichte 20: 271-388

Kreuz A (1995) Bericht über die botanische Untersuchung von fünf frühkaiserzeitlichen Erdproben der mittelneolithischen Fundstelle Oppershofen. In: Eisenhauer U, Seidel M, Eine Siedlungsgrube der älteren römischen Kaiserzeit aus Oppershofen, Wetteraukreis (Hessen). Ein Beitrag zur Besiedlungsgeschichte der Wetterau im 1. Jahrhundert nach Christi Geburt. Archäologisches Korrespondenzblatt 25: 187-189

Kroll H (1982) Kulturpflanzen von Tiryns. Archäologischer Anzeiger $467-485$

Kroll H(1994) Pflanzliche Grossreste aus einer Latrine vom Auerberg. In: Ulbert G, Der Auerberg I. Topographie, Forschungsgeschichte und Wallgrabungen. Münchner Beiträge zur Vor- und Frühgeschichte 45: 199-211

Kučan D (1992) Die Pflanzenreste aus dem römischen Militärlager Oberaden. In: Kühlborn JS, Das Römerlager in Oberaden III. Die Ausgrabungen im nordwestlichen Lagerbereich und weitere Baustellenuntersuchungen der Jahre 1962-1988. Bodenaltertümer Westfalens 27: 237-265

Kučan D (1995) Zur Ernährung und dem Gebrauch von Pflanzen im Heraion von Samos im 7. Jahrhundert v. Chr. Jahrbuch des Deutschen Archäologischen Instituts 110: 1-64

Kuijper WJ, Turner H (1992) Diet of a Roman centurion at Alphen aan de Rijn, The Netherlands, in the first century AD. Review of Palaeobotany and Palynology 73: 187-204

Küster H (1988) Granatäpfel (Punica granatum L.) im mittelalterlichen Konstanz. Archäologisches Korrespondenzblatt 18/1: 103-107

Maier F (1985) Vorbericht über die Ausgrabung 1984 in dem spätkeltischen Oppidum von Manching. Germania 63: 17-55

Marinval P (1993) Etude carpologique d'offrandes alimentaires végétales dans les sépultures gallo-romaines: réflexions préliminaires. In: Ferdière A (ed) Monde des morts, monde des vivants en Gaule rurale. Actes du Colloque ARCHAEA/AGER, Orléans, 7-9. fèvr. 1992. Orléans, pp 45-65

Martin-Kilcher S (in press) Amphoren. In: Hagendorn A, Doppler $\mathrm{H}$, Huber A, Hüster-Plogmann H, Jacomet S, Meyer-Freuler Ch, Pfäffli B, Schibler J (in press) Neue Forschungen zur Frühzeit von Vindonissa und den Lagern der 13. Legion. Veröffentlichungen der Gesellschaft Pro Vindonissa 18

Matterne-Zech V (2001) Agriculture et alimentation végétale durant l'age du Fer et l'époque gallo-romaine en France septentrionale. Montagnac, Monique Mergoil

Meyer FG (1988) Food plants identified from carbonized remains at Pompeii and other Vesuvian sites. In: Curtis RI (ed) Studia Pompeiana et Classica in Honour of Wilhelmina F. Jashemski, Vol. 1, New York, pp 183-220

Meyer-Freuler C (in press) Keramik. In: Hagendorn A, Doppler H, Huber A, Hüster-Plogmann H, Jacomet S, Meyer-Freuler Ch, Pfäffli B, Schibler J (in press) Neue Forschungen zur Frühzeit von Vindonissa und den Lagern der 13. Legion. Veröffentlichungen der Gesellschaft Pro Vindonissa 18

Muthmann F (1982) Der Granatapfel, Symbol des Lebens in der Alten Welt. Schriften der Abegg-Stiftung Bern 6. Office du Livre, Fribourg

Narten G-B (1999) Entwicklung eines Bestimmungsschlüssels für verkohltes Fruchtfleisch, Brot und Brei. Diplomarbeit Universität Basel

Neuweiler E (1908) Pflanzenreste aus der römischen Niederlassung Vindonissa. Vierteljahrschrift der Naturforschenden Gesellschaft Zürich 53: 393-407

Neuweiler E (1927) Liste der Pflanzenreste aus dem Kälberhügel Vindonissa. Vierteljahrsschrift der Naturforschenden Gesellschaft in Zürich 72: 326-331
Pals JP (1987) Het archaeobotanisch onderzoek. In: Vanderhoeven $\mathrm{R}$, Konijnenburg $\mathrm{R}$ van der, Boe $\mathrm{G}$ de, Het oudheidkundig bodemonderzoek aan de Kielenstraat te Tongeren. Archaeologia Belgica 3: 127-138

Petrucci-Bavaud $M$, Jacomet $S$ (in press) Die Ergebnisse der archäobotanischen Untersuchungen der Kulturschichten der Holzbauten. In: Schwarz P-A, Augst-Kastelen 1. Die vorrömische Besiedlung und die frührömischen Holzbauten. Forschungen in Augst 21

Pfäffli B, Schibler J (in press) Tierknochen (grössere Tiere). In: Hagendorn A, Doppler H, Huber A, Hüster-Plogmann H, Jacomet S, Meyer-Freuler Ch, Pfäffli B, Schibler J (in press) Neue Forschungen zur Frühzeit von Vindonissa und den Lagern der 13. Legion. Veröffentlichungen der Gesellschaft Pro Vindonissa 18

Pieters M, Bouchet F, Cooremans B, Desender K, Ervynck A, Neer $W$ van (1995) Granatappels, een zeeëngel en rugstreeppadden. Een greep uit de inhoud van een bakstenen beerput uit het $15 \mathrm{de}$ eeuwse Raversijde(Oostende, prov. West-Vlaanderen). Archeologie in Vlaanderen 5: 193-224

Plinius Secundus d. Ä. G Naturkunde Buch XVIII: Botanik: Ackerbau. Translated and edited by König R, Hopp J, Glöckner W in 1995. Artemis and Winkler, Zürich

Polunin O (1971) Pflanzen Europas. BLV München

Ricciardi M, Aprile GG (1988) Identification of some carbonized plant remains from the archaeological area of Oplontis. In: Curtis RI (ed) Studia Pompeiana et Classica in Honour of Wilhelmina F. Jashemski, Vol. I, New York 1988, pp 317-325

Roth L, Kormann K, Schweppe H (1992) Färbepflanzen - Pflanzenfarben. Ecomed, Zürich

Rüger E (1980) Die römischen Terrakotten von Nida-Heddernheim. Schriften des Frankfurter Museums für Vor- und Frühgeschichte 5 , Frankfurt/M

Schweinfurth G (1891) Aegyptens auswärtige Beziehungen hinsichtlich der Kulturgewächse. Zeitschrift für Ethnologie 23: 649-669

Stika H-P (1999) Approaches to reconstruction of early Celtic landuse in the central Neckar region in southwestern Germany. In: Proceedings of the 11th IWGP Symposium Toulouse 1998. Vegetation History and Archaeobotany 8: 95-103

Wiethold J (1993) Restes végétaux de l'époque de la La Tène finale sous forme de sédiment organique du bassin de la Fontaine Saint-Pierre. Revue Archéologique de l'Est et du Centre-Est 44: 351-360

Wiethold J (1996a) Late Celtic and early Roman plant remains from the oppidum of Bibracte, Mont Beuvray (Burgundy, France). Vegetation History and Archaeobotany 5: 105-116

Wiethold J (1996b) Fonctionnement socio-economique de l'oppidum du $2^{\circ}$ s. av. J.-C. au $1^{\circ}$ s. ap. J.-C. Analyse de macrorestes végétaux du Mont Beuvray. In: Bibracte. Centre archéologique européen du Mont Beuvray. Document final de synthèse, rapport triennal 1993-1995

Wiethold J (1998) Recherches archéobotaniques en France du Centre-Est. Rapport annuel Scientifique 1998 du Centre archéologique européen du Mont Beuvray. Glux-en-Glenne, pp 217-240

Wiethold J (2000) Sieben Jahre archäobotanische Analysen im Oppidum von Bibracte. Untersuchungen zur Landwirtschaft und Nahrungsmittelversorgung in der Spätlatènezeit und in frührömischer Zeit. In: Guichard V, Sievers S, Urban $\mathrm{OH}$ (eds) Le processus de l'urbanisation à l'âge de Fer / Eisenzeitliche Urbanisationsprozesse. Actes du Colloque des 8-11 juin 1998 (Glux-en-Glenne F-58). Glux-en-glenne: Centre Européen du Mont Beuvray, pp 203-209 (Bibracte 4)

Willerding U (1978) Die Pflanzenreste. In: Mackensen M, Das römische Gräberfeld auf der Keckwiese in Kempten. Materialhefte zur Bayerischen Vorgeschichte, Reihe A 34: 183-192

Zohary M, Hopf M (2000) Domestication of plants in the Old World. The origin and spread of cultivated plants in West Asia, Europe and the Nile Valley (3rd edition), Oxford University Press, Oxford 